\title{
The physical properties, lignin distribution, chemical composition of fibers and gas exchange rate of kenaf (Hibiscus cannabinus L.) varieties under prolonged water deficiency
}

\author{
H. Khalatbari', Z.E. Jaafar ${ }^{1 *}$, A. A. Khalatbari ${ }^{1}$, A.H. Hazandy ${ }^{2}$ and A. H. Mohd Ridzwan ${ }^{1}$ \\ ${ }^{1}$ Department of Crop Science, Faculty of Agriculture, Universiti Putra Malaysia, Serdang, Selangor, MALAY- \\ SIA, 43400 *Corresponding author: magnificent_pal@yahoo.com drhawazej.postgrads@gmail.com. ${ }^{2}$ Institu- \\ te of Tropical Forestry and Forest Products, Universiti Putra Malaysi, Serdang, Selangor MALAYSIA, 43400.
}

\begin{abstract}
The fundamental characteristics and physical properties of kenaf (Hibiscus cannabinus L.) fibers cultivated and subjected to three different water frequencies in Universiti Putra Malaysia, were analyzed. For deep analysis, which includes micro-scale viewing for identification of kenaf cell wall structure, fibers were viewed in order to study the physical characteristics, anatomy, and lignin distribution. The chemical composition was determined considering Technical Association of Pulp and Paper Industry (TAPPI) methods. Water stress treatments were imposed on the plants four weeks after germination when they had attained more than four leaves: daily watering based on soil field capacity (100\% ER; well watered), water stress imposition 1 month after seedling establishment completion (1MAS) and water stress imposition at flowering stage (AFS). Each water treatment was replicated three times in a randomized complete block design (RCBD) in split plot arrangement with water treatments as the main plots and the varieties as the sub-plots; irrigation system was applied for the purpose. Different water treatments and different varieties at the end of experimental period had significant impact on fiber dimensions and physiological attributes. Fiber quality attributes, gas exchange rate and growth parameters were affected in negative way when all varieties had been subjected to water stress regardless of time of stress imposition.
\end{abstract}

Keywords: Water frequency, cell wall structure, fiber dimensions, anatomy and lignin distribution 


\section{Introduction}

As we all know water is abundant on earth covering almost $71 \%$ of the total surface, its distribution is not uniform and can easily cause restrictions in availability to plants production. Such restrictions at global scale are easily observed in dry climates and can occur in other regions (IPCC, 2011). The impact of water restriction on losses in the production and distribution of plants on the earth are significantly larger than all other losses which are caused by biotic and abiotic factors. This huge impact of water on plants emerges from its physiological importance, being a fundamental factor for successful plant growth, involving photosynthesis and many other biochemical processes such as the synthesis of energetic composites and new tissue. Thus, in order to evaluate and determine the growth and productive behavior of plant species it is indispensable to have an understanding of plant water relations and the consequences of an inadequate water supply as well. Generally, the water state of each plant is controlled by relative rates of loss and absorption, additionally it depends on the ability to adjust and keep an adequate water status.

When a plant is under water deficit, there would be different types of responses at physiological, biochemical and molecular scale (Shao et al., 2008). Physiological responses are directly linked to a condition of recognition of stress by the root system, turgor changes and water potential and as a result stomatal conductance, internal $\mathrm{CO}_{2}$ concentration and photosynthetic activity would decrease. Considering biochemical terms, there will be a decrement in the photochemical activity of photosynthesis, Rubisco enzyme activity and the accumulation of secondary metabolites linked to stress (such as glutathione and polyamines). When plants go into a condition of water deficit and the cells hydration is reduced, abscisic acid and solutes will increase in the plant, especially in the root system (the increase in solutes take place in a relative manner, due to water reduction). These factors will bring reduction of stomatal conductance and photosynthetic activity which finally will result in a reduction in the synthesis of proteins and cell walls and a decrease in the rate of cell expansion as well (Taiz and Zeiger, 2006). The sum of these responses to water deficit contributes to explain the reduction of plant growth.

During the time, plants have developed ecological and physiological responses and strategies in order to cope with water shortages caused either by stress avoidance or stress tolerance. These types of responses allow them to survive and even to maintain some growth under adverse conditions. Plant response depends on the nature of the water shortage inducing physiological responses to short-term changes, acclimation to a certain level of water availability and adaptation to drought. Crop productivity and yield can be influenced by many physiological processes and environmental factors (Hattori et al., 2013; Quezada et al., 2011). It is well known that water deficit affects every aspect of plant growth, modifying anatomy, morphology, physiology and biochemistry (Eamus, 1991; Raza et al., 2013).

The high tolerability and quick recovery in kenaf is presumed to depend on photorespiration, by which the excessive energy in leaves was effectively dissipated to protect the photosynthetic apparatus. As mentioned above, the specific feature in photosynthetic response of kenaf is characterized by the following two points: one is the sustaining of a high $\mathrm{CO}_{2}$ exchange rate as a great $\mathrm{CO}_{2}$ sequester under the normal growth condition (Khalatbari et al., 2014) and the other is the increase in photorespiration rate under the drought conditions. Prolonged drought leads to retarded growth, reduced yield, and may cause death. There has been some debate as 
to whether kenaf avoids, tolerates or escapes drought. However few literature references have reported experimental results on the physiological attributes and fiber dimensions of this crop especially in term of either gas exchange rate and water relations and its relation with environmental and microclimatic factors.

Information relating water use efficiency of kenaf cultivars specifically these three varieties is very scanty and has not been explored in detail, and knowledge on this can hold the better perceptive of kenaf physiology that finally affects its growth, biomass productivity and the most prominent aspect which is fiber quality. The objectives of this study were: 1). To evaluate growth parameters of selected varieties especially growth attributes such as shoot height and stem diameter in terms of fiber yield under different water frequency. 2) To determine gas exchange rate and water relations of these varieties subjected to different times of water impositions. 3). To determine the best kenaf variety under water frequency treatment in terms of fiber quality focusing on lignocellulose attributes.

\section{Materials and Methods}

\subsection{Experimental site}

The experiment was conducted at glasshouse at Taman Pertanian University (TPU), Universiti Putra Malaysia (UPM). The experimental site was at latitude of $\mathrm{N} 02^{\circ} 59^{\prime}$, longitude E $101^{\circ} 43^{\prime}$ and altitude of $64 \mathrm{~m}$ above the sea level. The mean daily temperature was $28^{\circ} \mathrm{C}$ (min: 23 , max: 35$)$ with mean relative humidity of $80-90 \%$ and the photosynthetic active radiation (PAR) of 700 to $800 \mu \mathrm{mol} \mathrm{m}{ }^{-2} \mathrm{sec}^{-1}$.

\subsection{Plant material, study area}

Three kenaf varieties namely Fuhong (FH991), V36 and Kohn-Kaen 60 (KK60) were selected from first experiment. Seeds were sown in polyethylene bags with $16 \mathrm{~cm}$ diameter and $24 \mathrm{~cm}$ height containing approximately $12.5 \mathrm{~kg}$ of top soil on 15 th September 2012. When seedlings reached trifoliate stage only one healthy seedling per polyethylene bag was retained.

\subsection{Plant maintenance, irrigation system and watering regulation}

Water being supplied throughout the experiment using drip system in order to ensure efficient use of water as water supplied directly to the seedling root zone by pen dripper (Capacity of $4 \mathrm{~L} \mathrm{ha}^{-1}$ ). Irrigation system was controlled with automatic timer. Each seedling received $1.2 \mathrm{~L}$ of water daily, given four times in the morning $(9.00 ; 11.00)$, at noon $(14.00)$ and in the afternoon (17.00) (Nkaa, et al., 2007). For insect protection the Diazinone (O,O-diethyl O-2-isopropyl6-methylpyrimidin-4-yl phosphorothioate) was used as needed. Plants were fed with nutrient solution in a fertigation system. Nutrient solution formulation containing 200ppm N (nitrogen) and 300ppm K (potassium) as $\mathrm{NH}_{4} \mathrm{NO}_{3}$ and $\mathrm{K}_{2} \mathrm{SO}_{4}, 160$ ppm $\mathrm{P}$ (phosphorus) as $\mathrm{P}_{2} \mathrm{O}_{5}, 170 \mathrm{ppm} \mathrm{Ca}$ (calcium) $\mathrm{CaCl}_{2}$ and 0.2 ppm each of $\mathrm{Mn}$ (manganese) as manganese sulphate, $12 \mathrm{ppm} \mathrm{Fe}$ (iron) as Fe EDTA, $\mathrm{Cu}$ (copper) EDTA as $\mathrm{MnCl}_{2}, \mathrm{~B}$ (Boron) as $\mathrm{H}_{3} \mathrm{BO}_{3}$, $\mathrm{Zn}$ (zinc) EDTA as $\mathrm{ZnSO}_{4}$. Stock solution was dissolved in irrigation water with ratio 1:20 every week.

\subsection{Water treatment application}

The seedlings were subjected to uniform irrigation of $100 \%$ field capacity every day from sowing to 30 days after sowing. This was to ensure uniform seedling establishment before the imposition of the water treatments. Water stress treatments were imposed on the plants four weeks after germination when they 
had reached four-leaf stage. The plants were irrigated by drip irrigation system considering the method of evapotranspiration replacement (ER) (Klapwijk and De Lint, 1974). Soil water was maintained at field capacity by daily watering. There were 3 water treatments consist of daily watering $(100 \% \mathrm{ER}$; well watered), water stress imposition one month after seedling establishment completion (1 MAS) and water stress imposition at flowering stage (AFS). For water stress treatments, irrigation was hold for three days and then plants were subjected to normal watering for one day. All polybags initially received equal volumes of water to maintain them near to the predetermined polybag capacity (1.2 liter per $12.5 \mathrm{~kg}$ polybag with soil) and moisture lost by ER was replaced daily $(100 \%)$. The treatment started again for next three days. These intervals continued until the end of experiment. Calibration was done weekly to take care of changing water demands of the plants with age.

\subsection{Gas exchange parameters}

Photosynthetic gas exchange was measured at the end of experimental period using a portable photosynthesis system (LI-6400, LICOR, inc. Lincoln, Nebraska USA). Measurement of gas exchange was done following the procedures described by Kubota and Hamid (1992). As measurement environrnents, the instrument was set with a light intensity of 800 $\mu \mathrm{mol} \mathrm{m}-^{2} \mathrm{~s}^{-1}$ photosynthetic active radiation, leaf temperature of $30{ }^{\circ} \mathrm{C}$ and air relative humidity of $80 \%$ were used. The fully expanded leaves on 5 th nodes of plants were selected randomly in each experiment. In each experiment, 10 plants of each variety were measured in the morning at $0800 \mathrm{~h}$ to 1000 $\mathrm{h}$ as being recommended by Hiromi et al., (1999). 3 leaves of each plant were measured in each experiment giving a total of 30 measurements per variety were sampled every time.

\subsection{Water relationship parameters}

All water relations measurements were made on the fully expanded leaf at the 5 th node from the apex. Total water potential was determined in the glasshouse using Scholander pressure chamber (Model 615, Plant Water Status Console, Santa Barbara, CA). All measurements were made every 3 weeks in the evening at 1700 h to 1900 h (Ogbonnaya et al., 1998).

\subsection{Physical properties of fibers and their values}

Stem samples for the fiber studies were obtained from the second internode counting from the base. Small slices or slivers (fiber bundles) for maceration obtained from the bast and from the central wood core were macerated by $67 \% \mathrm{HNO}_{3}$ and then were boiled in water bath for 5 minutes (the time of boiling has been modified from 10 minutes to 5 minutes in order to prevent any fiber slivers deterioration which could be possibly done by presence of $67 \% \mathrm{HNO}_{3}$ ). Fiber suspension that had been dyed with toluidine was finally placed on microscope slides to be viewed. Fiber samples were teased on slides and viewed under a calibrated microscope for the determination of the following fiber dimensions below. A total of 8 fibers were measured for each sample and mean values calculated for fiber length (fl), fiber diameter (fd), fiber lumen diameter (fld) and fiber wall thickness (fwt) (Ogbonnya et al., 1998).

\subsection{Chemical analysis}

The proportions of chemical properties in these three varieties of kenaf bast and core fibres were determined based on approved standard of Technical Association of Pulp and Paper Industry (TAPPI standard). The percentage of lignin was determined by TAPPI standard T 222 os-74 using 72\% sulphuric acid. For 
holocellulose, it was based on the method of Wise et al., (1946) using sodium chlorite, 10\% acetic acid and acetone with a slight modification. The percentage of alpha cellulose was determined by TAPPI standard T 203 os using $8.3 \% \mathrm{NaOH}, 17.5 \% \mathrm{NaOH}$ and $2 \mathrm{~N}$ acetic acid. Alpha cellulose extractive was derived from holocellulose.

\subsection{Experimental design and statistical analysis}

Three watering regimes consist of daily watering (100\% ER; well watered), water stress imposition 1 month after seedling establishment completion (1MAS) and water stress imposition at flowering stage (AFS). Each water treatment was replicated three times in a randomized complete block design (RCBD) in split plot arrangement with watering treatments as the main plots and the varieties as the subplots. Data were analysed using analysis of variance using SAS version 9.2 (SAS Institute Inc., 2007). Mean separation test between treatments was performed using Duncan New Multiple Range Test (DNMRT) and $p$ - value of $\leq 0.05$ was regarded as significant. Correlations between variables were established by SPSS16.

\section{Results}

After 3 months of experimental period, physiological attributes and water relation except for total leaf number were significantly affected by the interaction between different times of water stress imposition at different growth stages and different varieties $(P \leq 0.05)$ (Table 1) . There were also obvious differences in the parameters recorded as a result of either differences in different times of water stress imposition or varieties used in this experiment, these attributes were found to be higher under control water treatment (no stress) compared to other 2 water stress imposition consist of 1 month after seedling completion (1MAS) and at flowering stage (AFS) (Table 1). Sufficient information on the impact of water stress on growth and the recovery which could probably occurs after stress is of value both for planning irrigation strategies and for assessing the prospects for production in tropical area like Malaysia.

Table 1. ANOVA split-plot arrangement based on randomized complete block designed (RCBD) for water relations and gas exchange rate attributes of three varieties of kenaf namely: FH991, V36 and KK60 subjected to three different water regimes.

\begin{tabular}{cccccc}
\hline SOV & d.f & $\begin{array}{c}\text { Net } \\
\text { photosynthesis } \\
\text { rate }\end{array}$ & $\begin{array}{c}\text { Water } \\
\text { potential }\end{array}$ & $\begin{array}{c}\text { Stomata } \\
\text { conductance }\end{array}$ & $\begin{array}{c}\text { Transpiration } \\
\text { rate }\end{array}$ \\
\hline Block & $\mathbf{2}$ & $0.05 \mathrm{n} . \mathrm{s}$ & $0.004 \mathrm{n} . \mathrm{s}$ & $0.0006 \mathrm{n} . \mathrm{s}$ & $0.0002 \mathrm{n} . \mathrm{s}$ \\
$\begin{array}{c}\text { A(water } \\
\text { regimes) }\end{array}$ & $\mathbf{2}$ & $235.14^{* *}$ & $2.64^{* *}$ & $2.68^{* *}$ & $2.14^{* *}$ \\
Error A & $\mathbf{4}$ & 0.23 & 0.002 & 0.0005 & 0.0006 \\
$\mathbf{B}($ Varieties $)$ & $\mathbf{2}$ & $1.14^{*}$ & $0.013^{*}$ & $0.31^{* *}$ & $0.39^{* *}$ \\
$\mathbf{A} \times \mathbf{B}$ & $\mathbf{4}$ & $2.67^{* *}$ & $0.01^{* *}$ & $0.010^{* *}$ & $0.27^{* *}$ \\
$\mathbf{C . V}$ & & 2.76 & 5.37 & 2.01 & 1.00 \\
\hline
\end{tabular}

**, Significant at $P \leq 0.01 ; *$, significant at $P \leq 0.05$; ns, not significant. (According to DMRT). 


\subsection{Gas Exchange measurement}

Gas exchange attributes like net photosynthesis rate and stomata conductance showed significant differences among the water treatments, different varieties and their interaction at the end of experimental period $(P \leq 0.05)$ (Table 1$)$. All varieties subjected to control water treatment with no stress attained higher value for gas exchange rate and water relation (Table 2). The highest value of net photosynthesis rate belonged to variety FH991 $\left(23.33 \mu \mathrm{mol} \mathrm{m}^{-2} \mathrm{~s}^{-1}\right)$ and it was followed by varieties KK60 with value of $23.27 \mu \mathrm{mol} \mathrm{m}^{-2} \mathrm{~s}^{-1}$ and V36 $21.63 \mu \mathrm{mol} \mathrm{m} \mathrm{m}^{-2} \mathrm{~s}^{-1}$. The lowest net photosynthesis rate of $11.37 \mu \mathrm{mol} \mathrm{m}^{-2} \mathrm{~s}^{-}$ 'belonged to variety KK60 subjected to water treatment of 1MAS. Varieties FH991 and V36 recorded photosynthesis rate of $13.06 \mu \mathrm{mol} \mathrm{m}^{-2} \mathrm{~s}^{-1}$ and 13.17 $\mu \mathrm{mol} \mathrm{m} \mathrm{s}^{-2} \mathrm{~s}^{-1}$ respectively (Table 2).

At the end of experimental period all varieties subjected to control water treatment (no stress) attained higher stomata conductance compared to plants under water treatments of 1 MAS and AFS (Table 2). Varieties FH991, KK60 and V36 significantly showed the highest value of stomata conductance of $1.15 \mathrm{~mol} \mathrm{~m}^{-2} \mathrm{~s}^{-1}$ and $1.04 \mathrm{~mol} \mathrm{~m}^{-2} \mathrm{~s}^{-1}$ and $1.00 \mathrm{~mol} \mathrm{~m}^{-2} \mathrm{~s}^{-1}$ respectively.

Interestingly, there was less difference of stomata conductance between plants subjected to control treatment and plants under water treatment of AFS. Variety FH991 recorded the stomata conductance of $0.98 \mathrm{~mol} \mathrm{~m}^{-2} \mathrm{~s}^{-1}$ under water stress imposition at flowering stage which was almost like water control treatment result. The lowest stomata conductance belonged to variety KK60 with water treatment of $1 \mathrm{MAS}$ with the value of $0.02 \mathrm{~mol} \mathrm{~m}^{-2} \mathrm{~s}^{-1}$ which was followed by varieties V36 and FH991 (0.03 $\mathrm{mol} \mathrm{m}^{-2} \mathrm{~s}^{-1}$ and $0.04 \mathrm{~mol} \mathrm{~m}^{-2} \mathrm{~s}^{-1}$ respectively) (Table 2).

Same with photosynthesis rate and stomata conductance, transpiration rate had higher value for varieties under control water treatment, but it was observed that plants under water treatment of AFS had almost same value for transpiration rate due to possessing also same stomata conductance (Table 2 ). The highest value for transpiration rate was recorded by variety FH991 $2.12 \mathrm{mmol} \mathrm{m}^{-2} \mathrm{~s}^{-1}$.

Varieties KK60 and V36 had transpiration rate value of $1.96 \mathrm{mmol} \mathrm{m}^{-2} \mathrm{~s}^{-1}$ and $1.88 \mathrm{mmol} \mathrm{m}^{-2} \mathrm{~s}^{-1}$ respectively. It was also observed that variety FH991 under water treatment of AFS recorded value of 1.89 mmol m $\mathrm{m}^{-2} \mathrm{~s}^{-1}$ which determined that high stomata conductance under this water treatment caused higher transpiration rate compared to water treatment of 1 MAS (Table 2). All varieties under water treatment of 1 MAS showed lower value for transpiration rate in which varieties FH991 and KK60 recorded the lowest value of $1.03 \mathrm{mmol} \mathrm{m}^{-2} \mathrm{~s}^{-1}$ and $1.05 \mathrm{mmol} \mathrm{m} \mathrm{m}^{-2} \mathrm{~s}^{-1}$ respectively. Variety $\mathrm{V} 36 \mathrm{had}$ value of $1.10 \mathrm{mmol} \mathrm{m}^{-2} \mathrm{~s}^{-1}$ (Table 2). 
Table 2. Means of photosynthesis rate, water potential, stomata conductance and transpiration rate of three different kenaf varieties subjected to three different water treatments $\mathrm{N}=3$.

\begin{tabular}{|c|c|c|c|}
\hline \multirow{2}{*}{ Varieties } & \multicolumn{3}{|c|}{ times of water stress imposition } \\
\hline & & At flowering stage & No stress \\
\hline \multicolumn{4}{|c|}{ Photosynthesis rate $\left(\mu \mathrm{mol} \mathrm{m}^{-2} \mathrm{~s}^{-1}\right)$} \\
\hline FH991 & $13.06 \pm 0.08^{\mathrm{e}}$ & $18.12 \pm 0.13^{\mathrm{cd}}$ & $23.33 \pm 0.12^{\mathrm{a}}$ \\
\hline V36 & $13.17 \pm 0.20^{\mathrm{e}}$ & $17.60 \pm 0.06^{\mathrm{d}}$ & $21.63 \pm 0.26^{\mathrm{b}}$ \\
\hline KK60 & $11.37 \pm 0.66^{\mathrm{f}}$ & $18.54 \pm 0.12^{\mathrm{c}}$ & $23.27 \pm 0.23^{\mathrm{a}}$ \\
\hline \multicolumn{4}{|c|}{ Water potential (Mpa) } \\
\hline FH991 & $-1.52 \pm 0.04^{\mathrm{d}}$ & $-0.87 \pm 0.02^{b}$ & $-0.30 \pm 0.03^{\mathrm{a}}$ \\
\hline V36 & $-1.33 \pm 0.02^{\mathrm{c}}$ & $-0.85 \pm 0.02^{b}$ & $-0.30 \pm 0.03^{\mathrm{a}}$ \\
\hline KK60 & $-1.33 \pm 0.03^{c}$ & $-0.82 \pm 0.02^{b}$ & $-0.33 \pm 0.02^{\mathrm{a}}$ \\
\hline \multicolumn{4}{|c|}{ Stomata conductance $\left(\mathrm{mol} \mathrm{m}^{-2} \mathrm{~s}^{-1}\right)$} \\
\hline FH991 & $0.04 \pm 0.01^{\mathrm{g}}$ & $0.96 \pm 0.01^{\mathrm{d}}$ & $1.15 \pm 0.01^{\mathrm{a}}$ \\
\hline V36 & $0.03 \pm 0.01^{\mathrm{g}}$ & $0.88 \pm 0.01^{\mathrm{e}}$ & $1.00 \pm 0.02^{\mathrm{c}}$ \\
\hline KK60 & $0.02 \pm 0.01^{\mathrm{g}}$ & $0.75 \pm 0.01^{\mathrm{f}}$ & $1.04 \pm 0.01^{\mathrm{b}}$ \\
\hline \multicolumn{4}{|c|}{ Transpiration rate $\left(\mathrm{mmol} \mathrm{m}^{-2} \mathrm{~s}^{-1}\right)$} \\
\hline FH991 & $1.03 \pm 0.01^{\mathrm{g}}$ & $1.89 \pm 0.01^{\mathrm{c}}$ & $2.12 \pm 0.01^{\mathrm{a}}$ \\
\hline V36 & $1.10 \pm 0.02^{f}$ & $1.79 \pm 0.01^{\mathrm{d}}$ & $1.88 \pm 0.01^{\mathrm{c}}$ \\
\hline KK60 & $1.05 \pm 0.01^{\mathrm{g}}$ & $1.65 \pm 0.01^{\mathrm{e}}$ & $1.96 \pm 0.01^{\mathrm{b}}$ \\
\hline
\end{tabular}

Means in the same row followed by different letters indicate a significant difference according to DMRT $(P \leq 0.05)$.

\subsection{Water relationship measurement}

The leaf water potential value at the end of experimental period is presented in Table 2. The water potential in the control plants had higher value, while plants under water stress especially water treatment of 1 MAS showed sharp decrease in water potential. Varieties FH991, V36 and KK60 recorded water potential of $-0.3 \mathrm{Mpa},-0.3 \mathrm{Mpa}$ and $-0.33 \mathrm{Mpa}$ respectively when subjected to control treatment. The severely drought plants under water treatment of 1 MAS especially variety FH991 reached water potential of -1.52
MPa whereas V36 and KK60 recorded water potential of -1.33 MPa (Table 2).

\subsection{Fiber dimension}

The effects of different water treatments on the fiber dimensional properties of three kenaf varieties are presented in Table 3. The core and bast fiber properties of the three kenaf varieties were affected by different water treatments but for different varieties it was significant for all attributes except for bast fiber length and core lumen diameter. The interaction 
between different varieties and different water treatment was not significant $(P \leq 0.05)$ (Table 3$)$. Considering varieties effect, the highest bast fiber diameter was obtained by varieties FH991 and V36 under control water treatment with value of $20.44 \mu \mathrm{m}$ and 20.24 $\mu \mathrm{m}$ respectively and was followed by variety KK60 with value of $17.72 \mu \mathrm{m}$ at the end of experimental period. The highest core diameter belonged to variety FH991 that recorded the value of $26.20 \mu \mathrm{m}$ and was followed by varieties KK60 and V36 with value of $24.58 \mu \mathrm{m}$ and $24.27 \mu \mathrm{m}$ respectively (Table 4 ).

Having considered the impact of different water treatments on fiber dimensions of these varieties, the highest bast and core fiber length of $2.59 \mathrm{~mm}$ and $0.91 \mathrm{~mm}$ was recorded when all varieties were under control water treatment (no stress). The lowest bast and core fiber length belonged to water treatment of 1 MAS with value of $1.62 \mathrm{~mm}$ and $0.64 \mathrm{~mm}$ respectively
(Table 4). The highest value of bast fiber diameter of $23.01 \mu \mathrm{m}$ and core fiber diameter of $26.95 \mu \mathrm{m}$ was recorded when plants were subjected to control water treatment. All varieties under water treatment of 1 MAS had lower bast and core fiber diameter with value of $15.66 \mu \mathrm{m}$ and $21.62 \mu \mathrm{m}$ respectively (Table 4). Control water treatment (no stress) recorded the highest bast and core lumen diameter $(10.17 \mu \mathrm{m}$ and 17.37 $\mu \mathrm{m})$ whereas the lowest value belonged to varieties under water stress treatment of 1 MAS for bast and core (7.11 $\mu \mathrm{m}$ and $14.24 \mu \mathrm{m}$ respectively) (Table 4). For cell wall thickness attribute it was observed that all varieties subjected to control water treatment attained the highest value for bast $(4.56 \mu \mathrm{m})$ and for core $(3.44 \mu \mathrm{m})$. Water treatment of 1 MAS had the lowest cell wall thickness for bast and core fiber (4.01 $\mu \mathrm{m}$ and $2.85 \mu \mathrm{m}$ respectively) (Table 4).

Table 3. ANOVA split-plot arrangement based on randomized complete block designed (RCBD) for bast and core fiber measurements of three varieties of kenaf namely: FH991, V36 and KK60 subjected to three different water regimes.

\begin{tabular}{|c|c|c|c|c|c|c|c|c|c|}
\hline SOV & d.f & $\begin{array}{l}\text { Bast fibre } \\
\text { length }\end{array}$ & $\begin{array}{l}\text { Bast fiber } \\
\text { diameter }\end{array}$ & $\begin{array}{l}\text { Bast lumen } \\
\text { diameter }\end{array}$ & $\begin{array}{l}\text { Bast cell } \\
\text { wall } \\
\text { thickness }\end{array}$ & $\begin{array}{l}\text { Core fibre } \\
\text { length }\end{array}$ & $\begin{array}{l}\text { Core fiber } \\
\text { diameter }\end{array}$ & $\begin{array}{l}\text { Core lumen } \\
\text { diameter }\end{array}$ & $\begin{array}{l}\text { Core cell } \\
\text { wall } \\
\text { thickness }\end{array}$ \\
\hline Block & 2 & $0.007 \mathrm{n} . \mathrm{s}$ & $0.30 \mathrm{n} . \mathrm{s}$ & 0.40 n.s & $0.03 \mathrm{n} . \mathrm{s}$ & $0.02 \mathrm{n} * *$ & $0.04 \mathrm{n} . \mathrm{s}$ & $0.76 \mathrm{n} . \mathrm{s}$ & $0.003 \mathrm{n} . \mathrm{s}$ \\
\hline $\begin{array}{l}\text { A(water } \\
\text { regimes) }\end{array}$ & 2 & $2.77 * *$ & $122.04 * *$ & $22.68 * *$ & $0.68 *$ & $0.16^{* *}$ & $78.43^{* *}$ & $28.23 * *$ & $0.81 * *$ \\
\hline Error A & 4 & 0.007 & 0.92 & 0.05 & 0.067 & 0.03 & 2.84 & 0.53 & 0.04 \\
\hline B(Varieties) & 2 & $0.02 \mathrm{n} . \mathrm{s}$ & $20.59 * *$ & $21.49^{* *}$ & $14.67 * *$ & $0.03 * *$ & $9.59 * *$ & $0.06 \mathrm{n} . \mathrm{s}$ & $0.63 * *$ \\
\hline $\mathbf{A} \times \mathbf{B}$ & 4 & $0.01 \mathrm{n} . \mathrm{s}$ & $0.53 \mathrm{n} . \mathrm{s}$ & $3.03 * *$ & $0.03 \mathrm{n} . \mathrm{s}$ & $0.002 \mathrm{n} . \mathrm{s}$ & $0.42 \mathrm{n} . \mathrm{s}$ & $0.33 \mathrm{n} . \mathrm{s}$ & $0.004 \mathrm{n} . \mathrm{s}$ \\
\hline C.V & & 5.26 & 6.82 & 7.96 & 7.68 & 6.02 & 2.98 & 3.63 & 5.86 \\
\hline
\end{tabular}

**, Significant at $P \leq 0.01 ; *$, significant at $P \leq 0.05$; ns, not significant. (according to DMRT). 
Table 4. Impact of different times of water stress imposition on fiber dimension of bast and core of three varieties of Kenaf Fuhong 991 (FH991), V36 and Kohn-Kaen 60 (KK60) N=9.

\begin{tabular}{|c|c|c|c|c|c|c|c|c|}
\hline \multirow{3}{*}{$\begin{array}{c}\text { WATER } \\
\text { TREATMENTS }\end{array}$} & \multicolumn{8}{|c|}{ FIBER DIMENSION } \\
\hline & \multicolumn{4}{|c|}{ Bast fiber } & \multicolumn{4}{|c|}{ Core fiber } \\
\hline & $\begin{array}{c}\text { Fiber } \\
\text { length } \\
(\mathrm{mm})\end{array}$ & $\begin{array}{c}\text { Fiber } \\
\text { diameter } \\
(\mu \mathrm{m})\end{array}$ & $\begin{array}{c}\text { Lumen } \\
\text { diameter } \\
(\mu \mathrm{m})\end{array}$ & $\begin{array}{c}\text { Cell wall } \\
\text { thickness } \\
(\mu \mathrm{m})\end{array}$ & $\begin{array}{l}\text { Fiber } \\
\text { length } \\
(\mathrm{mm})\end{array}$ & $\begin{array}{c}\text { Fiber } \\
\text { diameter } \\
(\mu \mathrm{m})\end{array}$ & $\begin{array}{c}\text { Lumen } \\
\text { diameter } \\
(\mu \mathrm{m})\end{array}$ & $\begin{array}{c}\text { Cell wall } \\
\text { thickness } \\
(\mu \mathrm{m})\end{array}$ \\
\hline Control & $2.59 \pm 0.01^{\mathrm{a}}$ & $23.01 \pm 0.44^{\mathrm{a}}$ & $10.17 \pm 0.20^{\mathrm{a}}$ & $4.56 \pm 0.17^{\mathrm{a}}$ & $0.91 \pm 0.01^{\mathrm{a}}$ & $26.95 \pm 0.45^{\mathrm{a}}$ & $17.37 \pm 0.51^{\mathrm{a}}$ & $3.44 \pm 0.16^{\mathrm{a}}$ \\
\hline $\begin{array}{l}1 \text { month after } \\
\text { seedling } \\
\text { establishment }\end{array}$ & $1.62 \pm 0.02^{\mathrm{b}}$ & $15.66 \pm 0.58^{\mathrm{c}}$ & $7.11 \pm 0.60^{\mathrm{c}}$ & $4.01 \pm 0.06^{\mathrm{b}}$ & $0.64 \pm 0.06^{\mathrm{c}}$ & $21.62 \pm 0.71^{\mathrm{b}}$ & $14.24 \pm 0.35^{\mathrm{b}}$ & $2.85 \pm 0.08^{\mathrm{c}}$ \\
\hline At flowering stage & $2.58 \pm 0.09^{\mathrm{a}}$ & $19.73 \pm 0.28^{\mathrm{b}}$ & $7.89 \pm 0.48^{\mathrm{b}}$ & $4.35 \pm 0.10^{\mathrm{a}}$ & $0.81 \pm 0.03^{b}$ & $26.48 \pm 0.77^{\mathrm{a}}$ & $17.25 \pm 0.46^{\mathrm{a}}$ & $3.23 \pm 0.09^{\mathrm{b}}$ \\
\hline
\end{tabular}

Means with different superscripts within column are significantly different according to DMRT $(P \leq 0.05)$

\subsection{Fiber values}

The effects of different water treatments on the fiber derived values of three kenaf varieties are presented in Table 5. For bast fiber, slender ratio and runkle ratio were affected by different water treatments but core it was just slender ratio which had significant difference among different water treatments $(P \leq 0.05)$. Different varieties had significant impact on all attributes. But there was no interaction between different varieties and different water treatment.

In this experiment, V36 when was under adequately watered control had the highest slender ratio for bast (126.83) which was followed by varieties FH991 (112.97) and KK60 (110). For core, there was no significant difference between varieties FH991 with slender ratio of 32.89 and V36 with slender ratio of 32.36 whereas variety KK60 had slender ratio of 29.39 (Table 6). Higher slender ratio under control water treatment is due to higher fiber length and lower fiber diameter which would bring higher quality to fiber. The highest bast coefficient of suppleness was recorded by variety FH991 (49.33) and was followed by varieties V36 (40.98) and KK60 (39.22).

For core, the highest coefficient of suppleness was recorded by varieties V36 with ratio of 66.79 and KK60 with ratio of 66.42 whereas variety FH991 attained the ratio of 62.60 (Table 6). Low runkel ratio $(\leq 1)$ is essential for proper and good paper characteristics. Therefore, it implies that runkel ratio determines the suitability of fiber for paper production. In this experiment the lowest bast rukle ratio was recorded by variety FH991 (0.60) and was followed by varieties V36 with ratio of 1.26 and KK60 with ratio of 1.40 . Considering core runkle ratio, the lowest ratio belonged to varieties KK60 and V36 with ratio of 0.36 . Variety FH991 attained the ratio of 0.42 (Table 6). 
Table 5. ANOVA split-plot arrangement based on randomized complete block designed (RCBD) for bast and core fiber yield and ratios measurement of three varieties of kenaf namely: FH991, V36 and KK60 subjected to three different water regimes.

\begin{tabular}{ccllllll}
\hline SOV & d.f & $\begin{array}{l}\text { Bast slender } \\
\text { ratio }\end{array}$ & $\begin{array}{l}\text { Bast } \\
\text { coefficient of } \\
\text { suppleness }\end{array}$ & $\begin{array}{l}\text { Bast runkle } \\
\text { ratio }\end{array}$ & $\begin{array}{l}\text { Core slender } \\
\text { ratio }\end{array}$ & $\begin{array}{l}\text { Core } \\
\text { coefficient of } \\
\text { suppleness }\end{array}$ & $\begin{array}{l}\text { Core runkle } \\
\text { ratio }\end{array}$ \\
\hline Block & $\mathbf{2}$ & $35.86 \mathrm{n} . \mathrm{s}$ & $7.45 \mathrm{n} . \mathrm{s}$ & $0.0004 \mathrm{n} . \mathrm{s}$ & $37.61 \mathrm{n} . \mathrm{s}$ & 17.07 & $0.0003 \mathrm{n} . \mathrm{s}$ \\
$\begin{array}{l}\text { A(water } \\
\text { regimes) }\end{array}$ & $\mathbf{2}$ & $1713.13^{* *}$ & $72.96 \mathrm{n} . \mathrm{s}$ & $0.10^{* *}$ & $41.38^{* *}$ & $4.88 \mathrm{n} . \mathrm{s}$ & $0.001 \mathrm{n} . \mathrm{s}$ \\
$\begin{array}{l}\text { Error A } \\
\text { B(Varieties) }\end{array}$ & $\mathbf{4}$ & 26.06 & 6.04 & 0.005 & 57.68 & 12.34 & 0.001 \\
$\mathbf{A B}$ & $\mathbf{2}$ & $726.97^{* *}$ & $262.59^{* *}$ & $1.66^{* *}$ & $31.96^{*}$ & $48.46^{* *}$ & $0.008^{* *}$ \\
$\mathbf{C . V}$ & $\mathbf{4}$ & $26.83 \mathrm{n} . \mathrm{s}$ & $38.56 \mathrm{n} . \mathrm{s}$ & $0.007 \mathrm{n} . \mathrm{s}$ & $9.80 \mathrm{n} . \mathrm{s}$ & $5.91 \mathrm{n} . \mathrm{s}$ & $0.0002 \mathrm{n} . \mathrm{s}$ \\
& & 8.07 & 10.24 & 10.18 & 7.61 & 4.02 & 6.59
\end{tabular}

**, Significant at $P \leq 0.01 ; *$, significant at $P \leq 0.05$; ns, not significant. (according to DMRT).

Table 6. Bast and core fiber values of three varieties of Kenaf (Fuhong 991 (FH991), V36 and Kohn-Kaen 60 (KK60)) under three water treatments (Control, water stress imposition after 2 months of growth (1 MAS) and water stress imposition at flowering stage initiation (AFS). $\mathrm{N}=9$.

\begin{tabular}{|c|c|c|c|c|c|c|}
\hline \multirow[t]{3}{*}{ VARIETIES } & \multicolumn{6}{|c|}{ FIBER VALUES } \\
\hline & \multicolumn{3}{|c|}{ Bast fiber } & \multicolumn{3}{|c|}{ Core fiber } \\
\hline & $\begin{array}{c}\text { Bast slender } \\
\text { ratio }\end{array}$ & $\begin{array}{c}\text { Bast } \\
\text { coefficient of } \\
\text { suppleness }\end{array}$ & $\begin{array}{c}\text { Bast runkle } \\
\text { ratio }\end{array}$ & $\begin{array}{l}\text { Core slender } \\
\text { ratio }\end{array}$ & $\begin{array}{c}\text { Core } \\
\text { coefficient of } \\
\text { suppleness }\end{array}$ & $\begin{array}{c}\text { Core runkle } \\
\text { ratio }\end{array}$ \\
\hline FH991 & $112.97 \pm 1.50^{\mathrm{b}}$ & $49.33 \pm 1.21^{\mathrm{a}}$ & $0.60 \pm 0.03^{\mathrm{a}}$ & $32.89 \pm 0.54^{\mathrm{a}}$ & $62.60 \pm 2.05^{\mathrm{b}}$ & $0.42 \pm 0.02^{\mathrm{b}}$ \\
\hline V36 & $126.83 \pm 3.34^{\mathrm{a}}$ & $40.98 \pm 0.31^{\mathrm{b}}$ & $1.26 \pm 0.02^{\mathrm{b}}$ & $32.36 \pm 0.81^{\mathrm{a}}$ & $66.79 \pm 0.51^{\mathrm{a}}$ & $0.37 \pm 0.01^{\mathrm{a}}$ \\
\hline KK60 & $110.00 \pm 5.98^{b}$ & $39.22 \pm 0.82^{b}$ & $1.40 \pm 0.15^{\mathrm{b}}$ & $29.39 \pm 0.31^{\mathrm{b}}$ & $66.42 \pm 1.64^{\mathrm{a}}$ & $0.37 \pm 0.01^{\mathrm{a}}$ \\
\hline
\end{tabular}

Means with different superscripts within column are significantly different according to $\mathrm{DMRT}(\mathrm{P} \leq 0.05)$ 


\subsection{Chemical properties}

The effects of different water treatments on the fiber chemical properties of three kenaf varieties are presented in Table 7. Bast and core lignocellulose properties of the three kenaf varieties were affected by different water treatments $(\mathrm{P} \leq 0.05)$. Different varieties had no significant impact on these properties except for bast holocellulose and there was no significant interaction observed except for bast lignin and core $\alpha$-cellulose (Table 7).
The chemical composition of kenaf lignocellulose is priceless information on feasibility of plant material for paper making purposes. The highest bast and core lignocelluloses belonged to all varieties under control water treatment (no stress) (Table 8). The highest bast holocellulose, $\alpha$-cellulose and lignin belonged to varieties under control treatment $(85.22 \%, 56.42 \%$ and $13.75 \%$ respectively). Core lignocellulose attributes attained highest percentages under control water treatment in which holocellulose recorded $83.17 \%$, $\alpha$-cellulose $46.85 \%$ and lignin $20.08 \%$ (Table 8 ).

Table 7. ANOVA split-plot arrangement based on randomized complete block designed (RCBD) for bast and core lignocellulose and fiber yield of three varieties of kenaf namely: FH991, V36 and KK60 subjected to three different water regimes.

\begin{tabular}{|c|c|c|c|c|c|c|c|}
\hline SOV & d.f & $\begin{array}{l}\text { Bast } \\
\text { holocellulose }\end{array}$ & $\begin{array}{l}\text { Bast } \alpha- \\
\text { cellulose }\end{array}$ & $\begin{array}{l}\text { Bast } \\
\text { lignin }\end{array}$ & $\begin{array}{l}\text { Core } \\
\text { holocellulose }\end{array}$ & $\begin{array}{l}\text { Core } \alpha- \\
\text { cellulose }\end{array}$ & $\begin{array}{l}\text { Core } \\
\text { lignin }\end{array}$ \\
\hline Block & 2 & $0.02 \mathrm{n} . \mathrm{s}$ & $1.85^{*}$ & $0.16 \mathrm{n} . \mathrm{s}$ & $0.49 \mathrm{n} . \mathrm{s}$ & $3.08 * *$ & $0.33 n . s$ \\
\hline $\begin{array}{l}\text { A(water } \\
\text { regimes) }\end{array}$ & 2 & $108.17 * *$ & $21.97 * *$ & $1.03 * *$ & $96.44 * *$ & $53.63 * *$ & $53.65 * *$ \\
\hline Error A & 4 & 0.07 & 1.07 & 0.03 & 0.06 & 0.72 & 0.32 \\
\hline $\mathbf{B}$ (Varieties) & 2 & $3.01 *$ & $1.18 \mathrm{n} . \mathrm{s}$ & $0.08 \mathrm{n} . \mathrm{s}$ & $0.76 \mathrm{n} . \mathrm{s}$ & $0.15 \mathrm{n} . \mathrm{s}$ & $0.06 \mathrm{n} . \mathrm{s}$ \\
\hline $\mathbf{A B}$ & 4 & $0.47 \mathrm{n} . \mathrm{s}$ & $0.70 \mathrm{n} . \mathrm{s}$ & $0.18^{*}$ & $0.75 \mathrm{n} . \mathrm{s}$ & $0.90 *$ & $0.3 \ln . \mathrm{s}$ \\
\hline C.V & & 0.94 & 1.21 & 1.66 & 0.92 & 1.06 & 2.37 \\
\hline
\end{tabular}

**, Significant at $\mathrm{P} \leq 0.01 ; *$, significant at $\mathrm{P} \leq 0.05$; ns, not significant. (according to DMRT).

The lowest bast and core lignocelluloses belonged to varieties under water stress treatment of 1 MAS. Bast holocellulose of $80.67 \%, \alpha$-cellulose of 56.42 and lignin of $13.75 \%$ were recorded when plants were under water stress of 1 MAS. Plants under water stress treatment of 1 MAS had lowest core holocellulose of
$78.63 \%, \alpha$-cellulose of $41.97 \%$ and lignin of 15.24 (Table 8). As it is presented in Table 7, different varieties had no significant impact on lignocellulose properties of bast and core except for bast holocellulose. There was no significant difference between varieties FH991 and V36 on bast holocellulose. 
Table 8. Effect of three different water treatments on Holocellulose, $\alpha$-cellulose and Lignin of three varieties of Kenaf including: Fuhong 991 (FH991), V36 and kohn-kaen 60 (KK60). N=9.

\begin{tabular}{|ccc|ccc|}
\hline \multicolumn{5}{|c|}{ Fiber lignocellulose } \\
\hline Bastfiber & \multicolumn{3}{c|}{ Core fiber } \\
\hline Holocellulose (\%) & $\begin{array}{c}\text { a-cellulose } \\
(\%)\end{array}$ & Lignin (\%) & Holocellulose (\%) & $\begin{array}{c}\text { a-cellulose } \\
(\%)\end{array}$ & Lignin (\%) \\
\hline $80.67 \pm 0.43^{\mathrm{c}}$ & $53.31 \pm 0.62^{\mathrm{c}}$ & $13.07 \pm 0.12^{\mathrm{c}}$ & $78.63 \pm 0.44^{\mathrm{c}}$ & $41.97 \pm 0.38^{\mathrm{c}}$ & $15.24 \pm 0.15^{\mathrm{c}}$ \\
& & & & & \\
$84.15 \pm 0.20^{\mathrm{b}}$ & $55.12 \pm 0.33^{\mathrm{b}}$ & $13.43 \pm 0.20^{\mathrm{b}}$ & $81.93 \pm 0.72^{\mathrm{b}}$ & $44.23 \pm 0.91^{\mathrm{b}}$ & $18.20 \pm 0.20^{\mathrm{b}}$ \\
$85.22 \pm 0.41^{\mathrm{a}}$ & $56.42 \pm 0.17^{\mathrm{a}}$ & $13.75 \pm 0.13^{\mathrm{a}}$ & $83.17 \pm 0.29^{\mathrm{a}}$ & $46.85 \pm 0.49^{\mathrm{a}}$ & $20.08 \pm 0.17^{\mathrm{a}}$ \\
\hline
\end{tabular}

Means with different superscripts within column are significantly different according to $\mathrm{DMRT}(\mathrm{P} \leq 0.05)$

\section{Discussion}

There are several available methods for scheduling irrigation of crops such as fixed time interval, meteorological variables, and soil moisture content that are not completely considered as satisfactory due to the scientific explanation in which plant growth is controlled directly by plant water status and then indirectly by soil water status and atmospheric conditions (Kramer, 1983). In this experiment important fundamental characteristics and physical properties of kenaf fibers were considered for water treatment application. For kenaf 1 month after seedling establishment until flowering phase $(20 \%$ of flowering) is critical period for fiber production and formation.

Khalatbari et al., (2015) earlier stated that growth is sensitive to a period of water stress which makes it important to have information on the effect of water stress on fiber quality of kenaf where the economic yield is based on all the above-ground growth and have been indicated in other studies by Shukor et al., (2009) and Hossain et al., (2011).
There have been many researchers highlighting the important impact of different water treatments as irrigation on kenaf yield. Banuelos et al. (2002) stated a strong response of some kenaf cultivars such as Tainung 2 and Everglades 41 to well-water treatment. In present study, higher stomata conductance, photosynthesis rate and transpiration rate belonged to all varieties under control water treatment (no stress) especially variety FH991. This result is due to lower water potential of plants which leads to higher stomata conductance and therefore higher gas exchange rate and higher photosynthesis rate. This result is in agreement with Kramer (1983) previously stated that when water deficit occurs in the soil, leaf water potential would decline thus, results in stomata closure and decrement of $\mathrm{CO}_{2}$ uptake and limitation in photosynthesis rate. Ultimately there will be wilting and dramatic impairment of many metabolic functions.

In present study it was observed that Kenaf can be described as opportunistic plant in relation with different water treatment. When soil water is available kenaf shows a high rate of stomatal conductance and transpiration but when water availability reduces leaf 
conductance and transpiration would decrease. This contrasts with wheat which shows a gradual decrease in photosynthesis as water deficit develops, but is in accordance with Ogbonnaya et al., (1998) which reported that water stress brought stomatal closure when watering was withheld therefore, transpiration rate fairly declined in the Kenaf plants under moderate and severe water stress. It was stated by Shaoyun et al., (2009) that, water potential and therefore leaf relative water content shows water status of plants whereas ion leakage explaining the injury of plasmalemma. In the study conducted by (Kramer, 1983), when kenaf matured, stomatal conductance and transpiration rate decreased even in the adequately watered control. All the levels of stress brought stomatal conductance and transpiration to almost zero. Kenaf was also observed to roll its leaves under drought condition but interestingly in present study no leaf rolling was observed for water stress treatment of AFS which probably describes a quick recovery by plants when were well-watered after stress imposition.

Results from this experiment showed that water stress treatments of 1 MAS and AFS had negative impact on the core and bast fiber dimensions when compared with adequately watered control which is not in agreement with the findings of Ogbonnaya et al. (1998) that reported water deficit had little or no effect on the bast and core fiber quality. Differences in fiber quality indicated that when plants were subjected to water stress fiber dimensions namely fiber length, fiber diameter, fiber lumen diameter and cell wall thickness changed. Plants subjected to water stress would have the reduction in transpiration rate which may also be attributed to some prominent morphological changes such as increased cell wall thickness and cell wall lignifications. Nkaa, et al., (2007) reported that core and bast fiber length of the three kenaf varieties were not adversely affected by water deficit. The optimum values of bast and core fiber elongation were obtained at late stage of growth. He also stated that this property was enhanced by the adequately watered control. In some studies optimum values of fiber lumen diameter obtained at the end of growth for both core and bast under the control water treatment and enhanced by moderate stress (Nkaa et al., 2007). Results from this experiment showed that water stress treatments of 1 MAS and AFS had negative impact on the core and bast slenderness ratio when compared with adequately watered control which is not in agreement with the findings of Ogbonnaya et al. (1998) that reported water deficit had little or no effect on the wood and bast slenderness ratio. Differences in ratios (fiber values) indicated that when plants were subjected to water stress fiber dimension namely fiber length, fiber diameter, fiber lumen diameter and cell wall thickness changed (these attributes are main components of fiber values) (N'kaa et al., 2007; Khalatbari et al., 2015).

Ververis et al., (2004) stated Kenaf fiber with low percentage of lignin needs low amount of pulping liquor for pulping fiber which is important for paper production industry. Ververis et al., (2004) also reported and suggested that the presence of low percentage of lignin indicated milder pulping condition with lower temperature and chemical charges to pulp kenaf. There was also a report by Khalatbari et al., (2015) and Nkaa et al., (2007) indicated that the chemical composition of bast and core samples from different cultivars grown under control and water stress conditions was different and core fiber had higher lignin percentage than bast fiber especially when plant had been irrigated well. 5 .

\section{Conclusion}

In conclusion, Growth, gas exchange rate and fiber quality attributes were affected in negative way when all varieties had been subjected to water stress regardless of time of stress imposition. 2 months after planting until $20 \%$ flowering stage is a critical period for 
fiber production and formation. In this study bast and core fiber dimensions was immensely affected by water stress especially after two months of growth. The use of Kenaf to source the paper industry makes ecological sense by preventing desert encroachment through forest conservation, while the use of wood-based fibres degrades the natural forests, destroys wildlife habitats and pollutes the environment. In this experiment kenaf varieties had different fiber dimension (differences in their length, diameter, lumen diameter and cell wall thickness) under different water treatments. Variety FH991 recorded higher fiber dimension in comparison with varieties V36 and KK60. The differences in plant fiber dimensions suggested that the varieties FH991 as a late maturing variety and V36 as an intermediate one can be considered for high quality fiber production when plants are well-watered.

\section{Acknowledgment}

The authors gratefully acknowledge Universiti Putra Malaysia (UPM) their contribution for this project number of 5523867 FRGS (Fundamental Research Grant Scheme).

\section{Refrences}

Banuelos, G.S., Bryla, D.R., Cook, C.G. 2002. Vegetative production of kenaf and canola under irrigation in central California. Ind. Crops Prod. 15, 237-245.

Eamus, D. 1991. The interaction between rising carbon dioxide and temperature with water use efficiency. Plant, Cell and Environment. 14, 843 - 852.

Hattori, D., Kenzo, T., Yamauchi, N., Irino, K.O., Kendawang, J.J., Ninomiya, I., Sakurai, K. 2013. Effects of environmental factors on growth and mortality of Parashorea macrophylla (Dipterocarpaceae) planted on slopes and valleys in a degraded tropical secondary forest in Sarawak, Malaysia. Soil Sci. Plant Nutr. 59, 218-228.

Henson, I.E., Jensen, C.R., Turner, N.C. 1989. Leaf gas exchange and water relation of Lupins and Wheat. 1. Shoot responses to soil water deficits. Aust. J. Plant Physiol. 16, 401-413.

Hiromi, H., Ninomiya, I., Koike, T., Ogino, K. 1999. Stomatal regulation of canopy trees in a tropical rain forest. Jpn. J. Ecol. 49, 68-76.

Hossain, M.D., Hanafi, M.M., Jol, H., Hazandy, A.H. 2011. Growth, yield and fiber morphology of kenaf (Hibiscus cannabinus L.) grown on sandy BRIS soil as influenced by different levels of carbon. AJB. 10(50), 10087-10094.

IPCC. 2011. Intergovernmental Panel of Climatic Change WGII, fourth assessment report.

Khalatbari, A.M., Jaafar, H.Z.E., Ali Khalatbari, A.A. 2014. The impact of $\mathrm{CO}_{2}$ enrichment on fiber dimension and lignocellulose properties of three varieties of kenaf (Hibiscus cannabinus L.). Journal of Soil Sci. Plant Nutr. 14, 676-687.

Khalatbari, A.M., Jaafar, H.Z.E., Khalatbari, A.A., Balouei, F. 2015. Physical and histochemical fiber properties of kenaf (Hibiscus cannabinus L.) affected by different water treatments. JFAE. 13, 71-76.

Khalatbari, A.M., Jaafar, H.Z.E., Khalatbari, A.A., Hazandy, A.H., Mohdid Ridzwan, A.H. 2015. The effect of different water regimes on growth, gas exchange rate and water relations of three varieties of kenaf (Hibiscus cannabinus L.) under glasshouse condition. JFAE. 13(1), 103-109.

Klapwijk, D., De Lint, P.J.A.L. 1974. Fresh weight and flowering of tomato plants as influenced by container type and watering condition. Acta Hort. $39,237-247$.

Kubota, F., Hamid, A. 1992. Comparative analysis of dry matter production and photosynthesis between mungbean (Vigna radiata L. Wlczek) and 
blackgram (Vigna mungo L. Hepper) grown in different light intensities. J. Fac. Agric. Kyushu Univ. 37, 71-80.

Kramer, P.J. 1983. Water Relations of Plants. New York: Academic Press.

N'kaa, F.A., Ogbonnaya, C.I., Onyike, N.B. 2007. Effect of differential irrigation on physical and histochemical properties of kenaf (Hibiscus cannabinus L.) grown in the field in Eastern Nigeria. Afri JAR. 2 (6), 252-260.

Ogbonnaya, C.I., Nwalozie, M.C., Roy-Macauley, H., Annerose, D.J.M. 1998. Growth and water relations of Kenaf (Hibiscus cannabinus L.) under water deficit on a sandy soil.Ind. Crops Prod. 8, 65-76.

Quezada, C., Fischer, S., Campos, J., Ardiles, D. 2011. Water management efficiency for carrot under drip irrigation in a haploxer and soil. J. Soil Sci. Plant Nutr. 11, 16-28.

Raza, M.A.S., Saleem, M.F., Shah, G.M., Jamil, M., Khan, I.H. 2013. Potassium applied under drought improves physiological and nutrient uptake performances of wheat (Triticum Aestivun L.). J. Soil Sci. Plant Nutr. 13, 175-185.
SAS. 2007. SAS/STAT User's Guide, Version 9.2. SAS Institute Inc., Cary, NC, USA.

Shaoyun, L., Chuanhao, C., Zhongcheng, W., Zhenfei, G., Haihang, L. 2009. Physiological responses of somaclonal variants of triploid bermudagrass (Cynodon transvaalensis x Cynodon dactylon) to drought stress. Plant Cell Rep. 28,517-526.

Shao, H., Chu, L., Shao, M., Jaleel, C.A., Mi, H 2008. Higher plant antioxidants and redox signalling under environmental stresses. C.R. Biologies. $331,433-441$.

Shukor, N.A., Hamzah, M.B., Hazandy, A.H., Salleh, G., Nasir, M.F. 2009. Growth and Phenology of Kenaf (Hibiscus cannabinus L.) Varieties. Pertanika J. Trop. Agric. Sci. 32, 29 - 33.

Taiz, L., Zeiger, E. 2006. Plant physiology, 4th ed. Massachusetts: Sinauer Associates Inc. Publishers.

Wise, L.E., Murphy, M., D’Addieco, A.A. 1946. Chlorite holocellulose, its fractionation and bearing on summative wood analysis and studies on the hemicelluloses. Pap. Trade J. 122(2), 35-43. 